\title{
CARACTERIZAÇÃO GEOFÍSICA DO SOLO PARA USO EM AGRICULTURA DE PRECISÃO
}

\author{
Claudia de Oliveira \\ Orientador: Dr. Jorge Luís Porsani (IAG-USP) \\ 137 p. - Dissertação (Mestrado) - Defesa 30.06.2006
}

\begin{abstract}
RESUMO. Nesta pesquisa são apresentados os resultados de investigações geofísicas, análises químicas e amostragem do solo com aplicações em agricultura de precisão. A área de estudo corresponde a um talhão destinado ao plantio de soja e algodão, localizada na Fazenda Farroupilha município de Pedra Preta-MT. No talhão foi realizado inicialmente um mapeamento regional da distribuição da condutividade elétrica através de perfis de CEC Caminhamento Elétrico Contínuo (sistema Veris 3100). A partir desses resultados foi selecionada uma área quadrada de $100 \mathrm{~m} \times 100 \mathrm{~m}$ para um estudo detalhado denominada de área piloto, a qual apresentava a maior heterogeneidade em termos de condutividade elétrica. Na área piloto foram empregados os métodos geofísicos GPR-Ground Penetrating Radar, TDR- Time Domain Reflectometry, EM38-Eletromagnético Indutivo e CEC; realizada amostragem de solo, a cada $10 \mathrm{~m}$, para as análises químicas e de componentes de solo. Durante a colheita de grãos foram obtidos os mapas de produtividade e do teor de umidade em todo talhão. A partir dos levantamentos geofísicos foram feitos mapas nas profundidades de 10,30, 90 e $150 \mathrm{~cm}$ correspondente às propriedades do solo, tais como, condutividade elétrica (CEC e EM38) e mapas de amplitude média dos refletores GPR através das antenas de 200 e $500 \mathrm{MHz}$. Com o TDR foi gerado um mapa do teor de umidade relacionado à profundidade de $10 \mathrm{~cm}$. A análise integrada desses resultados permitiu identificar regiões condutoras e resistoras que estão relacionadas com o solo mais úmido e mais seco, respectivamente. Os perfis GPR de 50 e $100 \mathrm{MHz}$ permitiram determinar uma camada de crosta laterítica enriquecida em óxido de ferro variando de 6,5 a $8 \mathrm{~m}$ e 0 topo do lençol freático ocorrendo em torno de 9,5 m de profundidade. Com os resultados das variáveis medidas na área piloto (dados geofísicos, análise química e componentes granulométricos do solo) e da produtividade, verificou-se, através dos modelos de regressão múltipla, que os elementos químicos que mais contribuem para explicar o valor da produtividade são: valor de pH (H20), teor de $\mathrm{Cu}$, valor de $\mathrm{pH}$ (CaCl2) e teor de Fe. Os componentes granulométricos do solo, argila, silte e areia também explicaram significativamente 0 valor da produtividade, bem como as medidas geofísicas correspondente aos valores de condutividade elétrica medida em $150 \mathrm{~cm}$ e 0 teor de umidade medido em $10 \mathrm{~cm}$. De uma maneira geral, os resultados geofísicos apresentaram uma boa concordância entre si e estão de acordo com as informações geológicas disponíveis para a área de estudos. A integração dos resultados geofísicos com as análises químicas e amostragem do solo mostrou um bom potencial em agricultura de precisão, podendo orientar a adubação e a irrigação do solo de áreas mais pobres em nutrientes (áreas mais resistoras e mais secas) e assim, poderia permitir um aumento na produção de grãos e otimizar os custos nos processos de cultivo.
\end{abstract}

ABSTRACT. In this research the results of geophysical investigation, chemical analysis and soil sampling with applications in precision agriculture are presented. The study area corresponds to field for the plantation of soy and cotton, in the Farroupilha Farm located near Pedra Preta city (MT). At first, a regional mapping of electric conductivity distribution was carried in there using Continuous Electric Profiles (CEC) (Veris 3100 system). From these results, a $100 \mathrm{~m} \times 100 \mathrm{~m}$ square area (pilot area) which presented the more heterogeneity electric conductivity values was selected for a detailed study. In the selected area were used geophysical methods GPR Ground Penetrating Radar, TDR - Time Domain Reflectometry, EM38 - Inductive Electromagnetic and CEC; soil sampling was carried every $10 \mathrm{~m}$, for chemical and soil components analysis. During the harvest of grains the maps of productivity and the moisture content of soil were obtained for all area. Geophysical surveys maps in the depths of 10,30, 90 and $150 \mathrm{~cm}$ corresponding to the properties of the soil, such as, electric conductivity (CEC end EM38) and maps of the average amplitude of reflectors GPR through the antennas of 500 and $200 \mathrm{MHz}$ were obtained. With the TDR a map of the moisture content related to the depth of $10 \mathrm{~cm}$ was obtained. The analysis of these results allowed identifying conductivity and resistivity regions that are related with the soil most humidity and drier, respectively. The GPR profiles of 100 and $50 \mathrm{MHz}$ permitted to determine a layer of lateritic crust enriched in iron oxide from $6.5 \mathrm{~m}$ to $8 \mathrm{~m}$ depth and the top of the water table occurring around $9.5 \mathrm{~m}$ depth. From the results of the measurements in the pilot area (geophysical data, chemical analysis and component sized of the soil) and the productivity of grain, it was verified by multiple regression models that the chemical elements that most contribute to explain the value of the productivity are: $\mathrm{pH}(\mathrm{H} 20), \mathrm{Cu}, \mathrm{pH}(\mathrm{CaCl} 2)$ and Fe. The soil components, clay, silt and sand also explained significantly the value of the productivity, as well as the corresponding geophysical measurements of the values of electric conductivity in $150 \mathrm{~cm}$ and the content moisture measured in $10 \mathrm{~cm}$. In general, the geophysical results showed a good agreement with each other and are in accordance with the available geologic information for the area of studies. The integration of the geophysical results with the chemical analysis and soil sampling showed a good potential applied to precision agriculture, being able to guide the fertilization and the irrigation of the soil of poor areas of nutrients (resistivity and dry areas) and thus, could allow to an increase in the production of grains and optimize the costs in the cultivation process. 